\title{
FARMA MIEJSKA JAKO NOWY SPOSÓB KSZTAŁTOWANIA KAMERALNYCH PRZESTRZENI MIESZKANIOWYCH. ANALIZA SPOSOBÓW I BARIER WDROŻENIA
}

\begin{abstract}
Miejskie rolnictwo pojawiło się w Europie jako odpowiedź na potrzebę bliższego kontaktu z naturą wśród mieszkańców miast, nie tylko w sposób bierny, poprzez wykorzystywanie już istniejących zasobów, lecz również w sposób czynny - jako sposób na kreowanie najbliższego środowiska między innymi dzięki własnoręcznej produkcji żywności. Farmy miejskie stanowią w tym przypadku element łączący miasto z jego "produktywną" alternatywą, tworząc możliwość budowy przestrzeni mieszkalnych o nowej jakości. Wraz z rozwojem rolnictwa miejskiego pojawiły się również nowe formy kształtowania niewielkich osiedli mieszkaniowych opartych na zasadach współużytkowania przestrzeni przez wybraną grupę ludzi lub jako atrakcyjny "dodatek" do ekskluzywnych osiedli w ścisłych centrach miast. Tego typu rozwiązania stwarzają szerokie pole do rozwoju nowych form urbanistycznych, łączących w sobie przestrzenie mieszkaniowe i rekreacyjne miast, jako miejsca integracji międzygatunkowej. Przykład holenderskiego miasta Almere ukazuje sposób kształtowania przestrzeni mieszkalnej człowieka na zasadach współistnienia z naturą w skali makro - poprzez tworzenia całych dzielnic - farm, jak w wypadku nowopowstającej Almere Oosterword. Na tym tle sytuacja Polski nie wygląda dobrze. Analiza samych uwarunkowań prawnych wykazała istnienie barier, które praktycznie uniemożliwiają rozwój krajowych farm miejskich na skalę, jaką znamy z realizacji europejskich.
\end{abstract}

Słowa kluczowe: przestrzeń międzygatunkowa, farmy wertykalne, miejska agrokultura, zamieszkanie ze zwierzętami

\section{Wprowadzenie}

Gwałtowny rozwój techniki oraz jej szybkie i nieodwracalne wkroczenie w życie człowieka spowodowało rewolucję w codziennym funkcjonowaniu. Już w początkach XIX wieku człowiek, którego zaczęły otaczać coraz to nowe, oraz trudniejsze do zrozumienia zdobycze techniki, zaczął pragnąć powrotu

\footnotetext{
${ }^{1}$ Justyna Kleszcz, Uniwersytet Zielonogórski, Wydział Budownictwa, Architektury i Inżynierii Środowiska, Katedra Architektury i Urbanistyki, ul. Szafrana 1, 65-516 Zielona Góra; tel. 6832823 08; j.kleszcz@aiu.uz.zgora.pl
} 
do życia prostego, samowystarczalnego, zbliżającego go do prostoty wymarzonego raju, arkadii. Mieszkańcy miast zapragnęli ponownego zbliżenia z naturą. Konsekwencje tych pragnień były różnorakie. Od przebudowy miast w celu rozluźnienia ich struktury, po tworzenie nowych założeń wychowania z bliższym kontakcie z przyrodą. Jednym z najnowszych sposobów na zbliżenie do natury w mieście jest powstanie i rozwój idei farmy miejskiej.

\section{Historia}

Pierwsze wizje miasta tak ściśle zespolonego ze strukturami agrarnymi sięgają XIX wieku i idei howardowskiego miasta - ogrodu [1] poprzedzonego wizją Nowej Atlantydy Francisa Bacona, stanowiących połączenie płaszczyznowej formy architektury mieszkaniowej z podobnie jednopłaszczyznową zielenią. Niedługo potem powstały pierwsze wizje łączące wertykalne, spiętrzone formy zamieszkania z uprawą roślin użytkowych. Z 1922 r. pochodzi niezrealizowany projekt le Corbusiera "Immeubles - villas". (rys. 1) Zamknięty kwartał w zabudowie galeriowej, z dwupoziomowymi mieszkaniami posiadał wolne przestrzenie - przynależne do każdego z mieszkań prywatne ogrody uprawne. Jako uzupełnienie tego założenia powstał w 1925 r. projekt "Cité jardin", który zakładał stworzenie pomiędzy kwartałami prywatnych terenów uprawnych przynależnych mieszkańcom oraz terenów sportowych dla rekreacji w bezpośrednim sąsiedztwie zamieszkania [2].

$\mathrm{Za}$ pierwsze współczesne $\mathrm{w}$ formie farmy miejskie uznaje się, powstałe w wyniku kryzysu ekonomicznego z lat 70-tych w Wielkiej Brytanii londyńskie Kentish Town City Farm (1972 r.) oraz Hackney City Farm (1984 r.) [3], [4], stanowiące przykład zabudowy zagrodowej, zaimplementowanej do miasta.
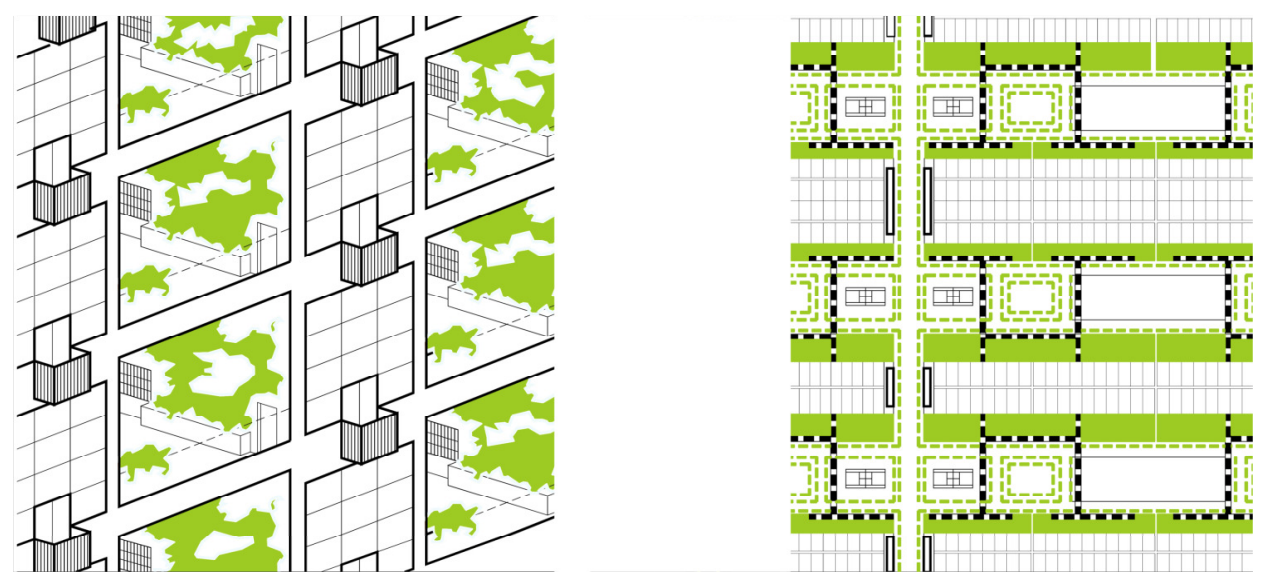

Rys. 1. Le Corbusier, niezrealizowane projekty Immeubles-villas z 1922 r. oraz Cité jardin z 1925 r. fragment ogrodów uprawnych

Fig. 1. Le Corbusier's unrealized projects: Immeubles-villas from 1922 and Cité jardin from 1925 a part of apartment - gardens 
Stałe zmniejszanie się zasobów żywności oraz wzrost poziomu urbanizacji spowodowały potrzebę powrotu do produkcyjnej formy samowystarczalnego miasta. Wprowadzenie $\mathrm{w}$ jego strukturę, zarezerwowanego $\mathrm{w}$ przeszłości dla produkcyjnego aspektu wsi, założenia farm oraz stworzenie nowej formy rolnictwa, które mogłyby powstać na terenach miejskich bez zaburzania antropogenicznego i kulturowego charakteru miasta stały się koniecznością. Nowa forma zabudowy, która powstaje poprzez swoją nietypową dla struktur zurbanizowanych funkcję, staje się nośnikiem wszelkich pomysłów związanych z kulturą rolną i zrównoważonym rozwojem środowiska miejskiego. Staje się to poprzez, m.in. wprowadzenie otwartości, jako jednej z głównych cech przestrzeni, dostępności dla lokalnej społeczności, poszerzenie programu funkcjonalnego farm miejskich o elementy stałego zamieszkania, edukacji, ekologii, terapii poprzez kontakt $\mathrm{z}$ naturą $\mathrm{i}$ in.

\section{Podstawowe dane}

\subsection{Definicja farmy miejskiej}

Wg definicji rolnictwo miejskie to rodzaj praktyki uprawy, przetwarzania i dystrybucji żywności, która następuje w/lub wokół wioski, małego, średniego lub dużego miasta. Rolnictwo to może obejmować hodowlę zwierząt, akwakulturę, zagospodarowanie terenów rolno-leśnych, pszczelarstwa i ogrodnictwa [5]. Pojęcie rolnictwa miejskiego nieco różni się od pojęcia i definicji miejskiej agrokultury, która opisuje zagadnienie produkcji żywności w miastach w sposób odmienny, zakładający, że miejska agrokultura jest to wytwarzanie żywności na obszarze miast [6] lub uprawa roślin i chów zwierząt na terenie miast oraz wokół nich [7]. Definicje te ulegają również poszerzeniu, określając produkcję rolną w miastach jako "działalność w zakresie wytwarzania, przetwarzania i dystrybucji produktów żywnościowych, nieżywnościowych, chowu zwierząt oraz upraw leśnych na terenie miast oraz obszarów podmiejskich" [8].

\subsection{Systematyka rolnictwa miejskiego}

Powyższe definicje rolnictwa miejskiego stanowią podstawę do usystematyzowania funkcjonalnego i strukturalnego typów obecnie powstających farm i ogrodów miejskich. Na wstępie trzeba jednak zaznaczyć jeszcze istotną różnicę, która występuje pomiędzy pojęciem miejskiego ogrodnictwa, w którym dominującą funkcją jest uprawa roślin, a zwierzęta stanowią jedynie uzupełnienie tej funkcji, od farm miejskich, gdzie hodowla i uprawa występują równocześnie, często z dominującą rolą chowu zwierząt gospodarskich. Wśród różnorodnych form, jakie przybiera miejskie rolnictwo, można wydzielić w szczególności podstawowe grupy wynikające z rodzaju prowadzonych upraw, techniki upraw, rodzaju hodowli, czy wreszcie rodzaju zajmowanej przestrzeni [9]. W wypadku próby łączenia funkcji farmy i zamieszkania w mieście istotna 
staje się lokalizacja części uprawnej i hodowlanej w stosunku do całości założenia. Podobnie ważne będzie rozróżnienie przestrzeni wydzielonych, uprawianych "pod nadzorem" lub zintegrowanych ze strukturą osiedla.

Wyraźny podział zaznacza się również w wypadku stopnia przynależności części uprawnej do mieszkańców. Może ona stanowić własność i być wyłącznie przez nich użytkowana, stanowiąc jednocześnie silne zdefiniowanie sposobu życia i przynależności grupowej. Nie jest tak jednak zawsze. W założeniach bardziej rozbudowanych zakłada się dowolność korzystania z części uprawnej i hodowlanej osiedla, poprzez dzierżawę lub usytuowanie obrzeżne, peryferyjne lub inne, które nie wymusza współużytkowania przez wszystkich mieszkańców. Istnieje również taki rodzaj przestrzeni mieszkalnych, które działają niezależnie od części uprawnej, ta zaś może być wykorzystywana przez miejskich hodowców całkowicie niezwiązanych z danym osiedlem (rys. 2).

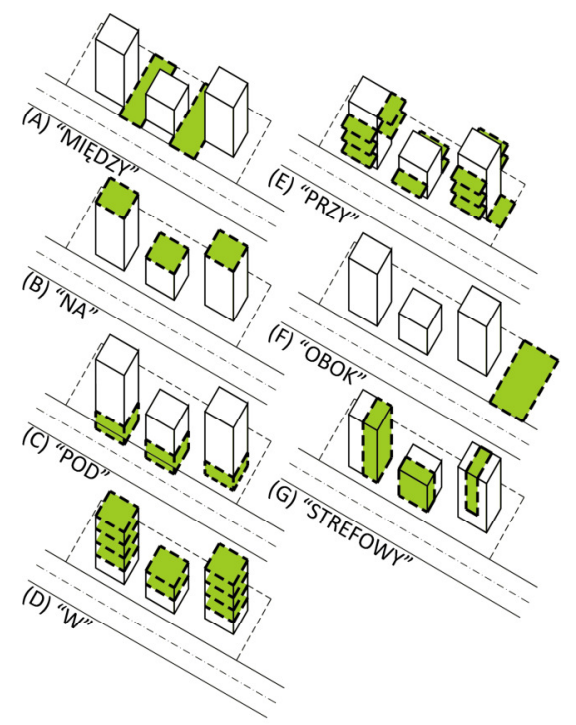

Rys. 2. Schemat lokalizacji farm miejskich w tkance urbanistycznej miast

Fig. 2. Location scheme of urban farms in the city

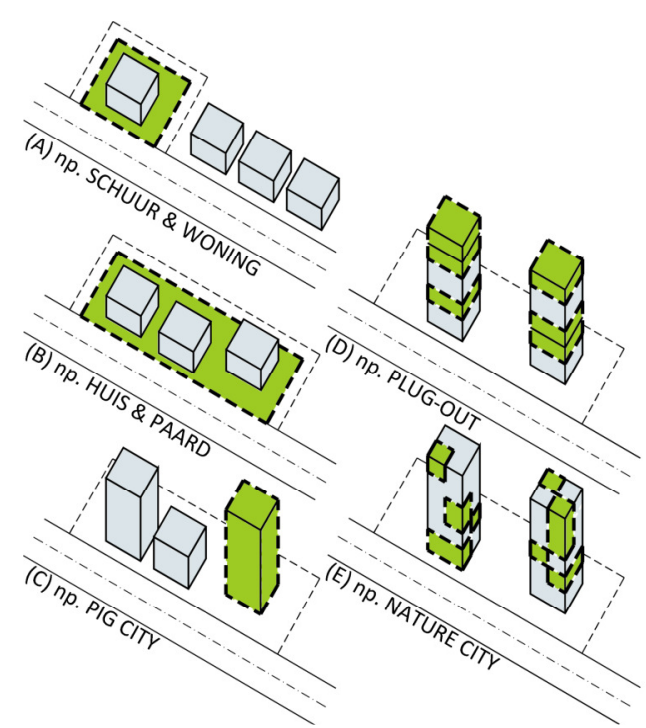

Rys. 3. Typologia miejskich farm mieszkalnych, a ich położenie w strukturze osiedla

Fig. 3. Typology of housing urban farms, and their location in settlement structure

Farma miejska już u zarania swojego powstania była związana ze sposobem zamieszkania różniących się od form historycznych. Obecnie przybiera ona wiele form, różnych pod względem formalnym, jak i funkcjonalnym, nadając im charakter ekstensywny lub intensywny w zależności od lokalizacji w mieście. Nadal podstawowym rozwiązaniem jest pozostawienie pojedynczych farm, stanowiących jednostki mieszkalne, często $\mathrm{z}$ domami jednorodzinnymi wewnątrz struktur o jednorodnym charakterze (rys. 3 A). Rozwinięciem takiego 
ekstensywnego układu jest wydzielenie niewielkich osiedli (rys. 3 B). W skrajnych przypadkach podejmowane są jednak próby tworzenia całych dzielnic w oparciu o taki właśnie typ przestrzeni, jak w wypadku Almere Oosterword - idei Agromere autorstwa wspominanej tu często pracowni MVRDV [10]. Intensywniejszą zabudowę, właściwą dla ośrodków centralnych w miastach można uzyskać poprzez stworzenie zespołów, w których funkcje zostają wydzielone punktowo $\mathrm{w}$ ramach jednego założenia, tworząc osobno typową zabudowę mieszkaniową wielorodzinną oraz zgrupowane, wydzielone przestrzenie przeznaczone na intensywną uprawę i chów (rys. $3 \mathrm{C}$ ). Takie strefowanie występuje np. w wypadku koncepcji Pig Farm autorstwa MRDV. Obecnie najszerzej dyskutowanymi wariantami połączenia funkcji mieszkalnej i rolnej są formy skupiające obie funkcje w zwartych, wysokich budynkach. Nawiązują one często do formy zabudowy kwartałowej lub wysokościowej, tworząc niezależne megastruktury mieszkalno - uprawne. Pod względem funkcjonalnym dzielą się one na układy z wertykalną segregacją funkcji oraz z oboma funkcjami rozmieszczonymi równomiernie (rys. $3 \mathrm{D}, \mathrm{E}$ ). Do najnowszych przykładów studialnych opracowań tego typu należą Plug - Out pracowni WORK ac z 2009 r. jako propozycja dla centrum Nowego Jorku, Aberrant Architecure dla Chicago autorstwa Scotta Johnsona z 2010 r., czy propozycja Vincenta Callebaut dla indyjskiego miasta Jaypee z 2016 r., czy wreszcie Homefarm w Singapurze pracowni SPARK z 2015 r.

Istotnym elementem analizy jest również określenie genezy powstania osiedla - farmy. Farma mieszkalna może powstawać jako samoistna, wcześniej zdefiniowana przestrzeń, jako element układu wielofunkcyjnego albo wtórnie jako sposób rewaloryzacji przestrzeni mieszkalnej istniejącej. Największy potencjał wydaje się mieć $\mathrm{w}$ tym przypadku, oprócz rozwiązań powstających na surowym korzeniu - tworzenie farm zintegrowanych z zabudową mieszkaniową, a powstałych poprzez nadbudowę, czy przebudowę istniejących obiektów. Znaczenie farm w procesie rewaloryzacji poprzez dużą elastyczność możliwych rozwiązań powoduje, że projekty takie jak Urban Farmers Aquaponic Rooftop Farm w Bazylei z 2012 r., autorstwa Conceptual Devices, mają wszelkie predyspozycje by stać się rozwiązaniem powszechnym.

Miejska farma mieszkalna stała się jednocześnie tworzywem artystycznym lub funkcją włączoną w większe, zwarte obiekty i założenia. Przykładem tego typu działania jest projekt Schuur \& Woning autorstwa holenderskiej pracowni Jelle de Jong Architekten, zakładający połączenie w jednym kompleksie zabudowy wielorodzinnej, farmy i produkcji żywności. Podobne projekty mieszkania ze zwierzętami zaczęły powstawać kilka lat wcześniej, jednak z mniejszym rozmachem. O ile mieszkanie z psem czy kotem jest silnie zakorzenione w kulturze, o tyle mieszkanie np. z końmi jest w proponowanej formie nowością, związaną z postępem cywilizacyjnym i uniezależnieniem człowieka od pracy tych ostatnich. Niezrealizowany projekt tego typu to Huis \& Paard autorstwa Laury Weeber z 2013 roku położony w dzielnicy Almere Hout Noord. Zakładał on możli- 
wość łączenia funkcji mieszkalnej z utrzymaniem koni i zapleczem oraz trasami rekreacyjnymi dla mieszkańców. Mniejsze założenia obejmują łączenie funkcjonalne jednostek mieszkalnych oraz otwartych farm, stajni czy ośrodków jeździecko - terapeutycznych z niewielkimi elementami pokoi gościnnych, salek szkoleniowych itp., służące częściej kulturalnej rekreacji wybranej grupy.

Jak wykazuje poniższa krótka analiza możliwość łączenia funkcji mieszkaniowej na terenach zurbanizowanych z funkcją produkcji żywności wydaje się logiczna i uzasadniona, co wykazują liczne realizacje. Dlaczego jednak w Polsce tego typu farm miejskich nie przybywa? Czy też innymi słowy - dlaczego w ogóle nie powstają? Spróbujmy wyjaśnić to zagadnienie.

\section{Sytuacja prawna farm miejskich w Polsce. Zwierzęta gospodarskie w miastach}

Na sytuację prawną farm miejskich w Polsce składa się wiele czynników. Ich najbardziej widomym efektem jest w rzeczywistości brak typowych form farm miejskich. Jak wykazuje nawet pobieżny przegląd zapisów mediów społecznościowych i podejmowanych inicjatyw społecznych, ludzie są chętni do podjęcia tego typu inicjatyw zwłaszcza jeśli kojarzą je z ogólnodostępnymi, zadbanymi terenami zieleni w mieście. Dlaczego więc nic się nie zmienia?

Pierwszym istotnym elementem są istniejące zapisy miejscowych placów zagospodarowania przestrzennego, które ściśle definiują funkcje poszczególnych terenów. $\mathrm{Z}$ założenia jest to działanie mające na celu wprowadzenie ładu przestrzennego, choć w wypadku farm miejskich działają skrajnie ograniczająco, jeśli wręcz nie zakazują całkowicie wprowadzania funkcji okołorolnych, w tym chowu i hodowli zwierząt na terenie śródmieść polskich miast. Na przykładzie Wrocławia można łatwo zaobserwować proces rugowania pozostałych fragmentów terenów rolnych, w których utrzymywane są zwierzęta, np. konie i zastępowanie ich "funkcjami miastotwórczymi". Dodatkowo sytuację komplikują zapisy ustawy o hodowli zwierząt, która zakazywała wszelkiej hodowli, poza hobbystyczną, zwierząt takich, jak psy czy koty, na obszarach w granicach administracyjnych polskich miast. Jednak jak pokazywało samo życie, w znacznej części przypadków był to przepis martwy, choć znacznie utrudniający życie mieszkańcom, chcącym hobbystycznie hodować zwierzęta takie, jak gołębie, czy pszczoły, nie mówiąc już o koniach, trzodzie chlewnej czy drobiu. Sytuacja nieco się poprawiła wraz $\mathrm{z}$ wprowadzeniem zmiany w Ustawie o utrzymaniu czystości i porządku w gminach w 2013 roku, w której to gminy zostały zobowiązane do określenia regulaminu utrzymania czystości i porządku na terenie gminy, a w nim w szczególności "(...) wymagań utrzymywania zwierząt gospodarskich na terenach wytaczonych z produkcji rolniczej, w tym także zakazu ich utrzymywania na określonych obszarach lub w poszczególnych nieruchomościach (...)" [11], co stworzyło furtkę dla rozwoju nie tylko miejskiego rolnictwa, którego bezpośrednio dotyczyły dotychczasowe zakazy, lecz również in- 
nych funkcji bazujących na kontakcie ze zwierzętami, przenosząc ciężar decyzji bezpośrednio na władze gminne.

W wypadku większości polskich miast, np. Wrocławia wprowadzone przepisy nadal w znacznym stopniu ograniczają możliwość tworzenia miejsc innych, niż hipoterapeutycznych na terenach miejskich. ${ }^{2}$ Dopuszczenie hodowli jedynie koni, a także królików oraz drobiu, przy jednoczesnym ograniczeniu możliwości utrzymania innych zwierząt gospodarskich poza placówkami naukowymi i jednostkami badawczymi, gdzie mogą być one utrzymywane jedynie w celu prowadzenia badań naukowych powoduje, że jedyną możliwą formą tworzenia farm miejskich jest potencjalnie możliwe tylko pod warunkiem ich doświadczalnego charakteru. Inną potencjalnie możliwą formą wprowadzenia gatunków innych, niż wspomniane w Regulaminie, jest wprowadzenie funkcji farmy miejskiej na terenach wyłączonych z niniejszych regulacji, co jednak znacznie ogranicza zasięg przestrzenny i swobodę wyboru terenu. Analiza regulaminów obowiązujących w największych polskich miastach ukazuje skrajną dowolność w rozwiązywaniu kwestii obecności w nich zwierząt. Spektrum przypadków ukazuje rozwiązanie prawne wprowadzone w Opolu, gdzie miasto pozostało podzielone na trzy strefy związane z typem zabudowy i stopniem uciążliwości potencjalnej hodowli dla mieszkańców. Odmienna sytuacja nastąpiła w Poznaniu, który w regulaminie gminnym pominął całkowicie kwestię zwierząt gospodarskich, pozostając przy całkowitym zakazie ich utrzymania w miastach wprowadzonym w ustawie o hodowli zwierząt. Najbardziej typowe rozwiązania przyjął wspomniany już Wrocław, gdzie rozszerzono grupę gatunków dopuszczonych do hodowli na terenie miasta. Wrocławski regulamin zakazał jednak rygorystycznie utrzymywania koni na nieruchomościach wykorzystywanych na cele mieszkalne.

\section{Wnioski}

Jak wykazała powyższa analiza, farmy miejskie stają się obecnie uzupełnieniem funkcji mieszkalnej $w$ miastach. Są jednocześnie odpowiedzią na rosnące potrzeby żywieniowe mieszkańców, m.in. minimalizują koszty produkcji żywności, jak również na rosnącą potrzebę kontaktu z przyrodą. Stanowiąc kolejną $\mathrm{z}$ form zieleni miejskiej, farmy takie uzupełniają pewną lukę w przestrzeni, która powstaje z powodu rozlewania się miast i zagarniania kolejnych fragmentów dzikich przyrodniczo. Choć jednoznacznie pozytywne, w Polsce tworzenie tego typu przestrzeni staje się jednak praktycznie nieosiągalne ze względu na obowiązujące przepisy prawa, i nie tylko. Dlatego w tym

\footnotetext{
${ }^{2}$ Dla Wrocławia określono, że " Na terenach wyłączonych z produkcji rolniczej można utrzymywać konie do celów rehabilitacyjnych, rekreacyjnych i sportowych, a także króliki oraz drób,..." Uchwała nr XXXV/780/12 Rady Miejskiej Wrocławia z dn. 29.11.2012 r. w sprawie ustalenia regulaminu utrzymania czystości i porządku na terenie Wrocławia. § 15.1.
} 
momencie istotnym staje się podjęcie dyskusji na temat takiej zmiany sytuacji prawnej w kraju, by powstawanie farm miejskich połączonych z zamieszkaniem ludzi w miastach stało się możliwe.

Tradycja ogrodów działkowych - rodzinnych, robotniczych, pracowniczych i innych, która jest nadal bardzo żywa w Polsce, jako jedna $z$ form rekreacji oraz, już nieco w mniejszym stopniu, dożywiania mieszkańców miast staje się paradoksalnie jedną $\mathrm{z}$ barier tworzenia $\mathrm{w}$ miastach innych form rolnictwa lub ogrodnictwa. Tocząca się w ciągu ostatnich kilkunastu lat ożywiona dyskusja nad przyszłością terenów de facto wyłączonych z ogólnego użytkowania i dostępnych wyłącznie dla zrzeszonych działkowców z danego terenu, wygrodzona i zamknięta dla okolicznych mieszkańców nie tworzy atmosfery przychylnej dla powstawiania jakichkolwiek form "zieleni aktywizującej", zwłaszcza tej połączonej bezpośrednio $\mathrm{z}$ terenami zamieszkania. W momencie, gdy na świecie forma ogrodów społecznych, rodzinnych, edukacyjnych, czy tymczasowych staje się metodą na aktywizację społeczną niefunkcjonujących poprawnie osiedli mieszkaniowych, w Polsce stanowi ona synonim zamknięcia oraz segregacji, podobnie jak zamknięte strzeżone osiedla.

W podobny sposób nie wytworzyła się w Polsce do tej pory forma miejskiego rolnictwa intensywnego, połączonego z hodowlą, głównie ze względu na kojarzenie tego typu działalności z zagrożeniem sanitarnym, nieczystościami, hałasem oraz nieprzyjemnym zapachem związany z brakiem zachowania podstawowych wymogów sanitarnych. W najlepszym wypadku kojarzona jest $\mathrm{z}$ hobbystyczną hodowlą gatunków takich, jak gołębie, króliki itp. Nierzadko też w zbiorowej pamięci pozostają relacje $\mathrm{z}$ okresu "zaludniania" miast dawnymi mieszkańcami wsi, hodujących drób w wannach, a kozy i świnie na balkonach nowo wybudowanych blokowisk. Pokłosiem owego skojarzenia rodem z serialu "Alternatywy 4" Stanisława Barei jest właśnie ciągła, choć stopniowo malejąca niechęć, również prawodawców i władz miejskich do wprowadzania różnych form rolnictwa w przestrzenie osiedli $\mathrm{w}$ celu ich rewitalizacji i stwarzania nowej jakości życia w mieście, w kameralnych, lecz miejskich założeniach urbanistycznych.

\section{Literatura}

[1] Howard E.: Garden Cities of To-Morrow, Faber and Faber, Londyn 1946, s. 50-57.

[2] http://www.fondationlecorbusier.fr/ \{dostęp 15.05.2016 r. \}.

[3] http://40years.ktcityfarm.org.uk/ \{dostęp 15.05.2016 r. .

[4] http://hackneycityfarm.co.uk/about/history \{dostęp 15.05.2016 r.\}.

[5] Poulsen M., Spiker M.: Integrating Urban Farms into the Social Landscape of Cities. Recommendations for Strengthening the Relationship Between Urban Farms and Local Communities, Johns Hopkins Bloomberg School of Public Health, Baltimore 2014, s. iii.

[6] Ackerman K.: The Potential for Urban Agriculture in New York City. Growing Capacity, Food, Security, \& Green Infrastructure. Columbia University, Columbia 2012. 
[7] Sroka W.: Definicje oraz formy miejskiej agrokultury - przyczynek do dyskusji, Wieś i Rolnictwo, vol. 164, no. 3, 2014, s. 88.

[8] Mougeot L.J.A.: Urban Agriculture: definition, presence, potential and risks. [w:] Bakker N.: Growing Cities, growing food: urban agriculture on the policy agenda. A reader on Urban agriculture, German Foundation for International Development (DSE), Feldafing 2000.

[9] Dubbeling, M., Merzthal G.: Sustaining urban agriculture requires the involvement of multiple stakeholders, [w:] Van Veenhuizen (red., Cities farming for future, Urban Agriculture for green and productive cities, RUAF Foundation, IDRC and IIRP, ETC-Urbanagriculture, Leusden 2006, s. 20-51.

[10] Jansma, J.E., Visser, A.J., Dekking A., Veer E.: Urban Agriculture: How to Create a Natural Connection between the Urban and Rural Environment in Almere Oosterwold (NL), REAL CORP 2013: PLANNING TIMES, Holandia 2014, s. 1373-1382.

[11] Ustawa z dn. 13 września 1996 r. o utrzymaniu czystości i porządku w gminach, Dz.U. 2013 poz. 1399.

\title{
URBAN FARM AS A NEW WAY OF FORMING INTIMATE RESIDENTIAL ENVIRONMENT. ANALYSIS OF METHODS AND BARRIERS OF IMPLEMENTATION
}

\begin{abstract}
S u m m a r y
Urban agriculture came to Europe as an answer to the need of closer contact with natural environment for people living in modern cites and urban areas, not only in the passive form, but also active - as a way of creating their own housing environment through producing their own food. Urban farms become, it this specific event, the element connecting city and its "productive" alternative, enabling the possibility to build a residential space of a new quality. Simultaneously with development of city farming, new forms of intimate housing are being created. It bases on rules of sharing space by chosen group or as attractive "extras" to exclusive residential sites in city centres. This type of urban solutions creates an opportunity to develop new urban forms, joining residential space with recreational function of the city, as a place for cross - species integration. An example of Almere shows the way of forming intimate residential environment basing on coexistence with nature in macro scale - through building whole district farms, as in the example of Almere Oosterword. In comparison to these examples Poland falls flat. Analysis of the same legal conditions revealed the existence of barriers which make the development of national urban farms sized as we know from the European examples practically impossible.
\end{abstract}

Keywords: interspecific area, vertical farming, urban agriculture, living with animals

DOI:10.7862/rb.2016.197

Przestano do redakcji: 19.05.2016 $r$.

Przyjęto do druku: 30.11.2016 $r$. 